\title{
Where Things Stand with Hazardous Waste Regulation
}

\author{
Sarah L. Stafford \\ College of William and Mary, slstaf@wm.edu
}

Follow this and additional works at: https://scholarworks.wm.edu/aspubs

Part of the Public Policy Commons

\section{Recommended Citation}

Stafford, Sarah L., Where Things Stand with Hazardous Waste Regulation (2010). Issues of the Day: 100 Commentaries on Climate, Energy, the Environment, Transportation, and Public Health Policy. https://scholarworks.wm.edu/aspubs/595 accepted for inclusion in Arts \& Sciences Articles by an authorized administrator of W\&M ScholarWorks. For more information, please contact scholarworks@wm.edu. 
ISSUES OF THE DAY

100 Commentaries on Climate, Energy,

the Environment, Transportation,

and Public Health Policy

climate gasges

TAXES

markets

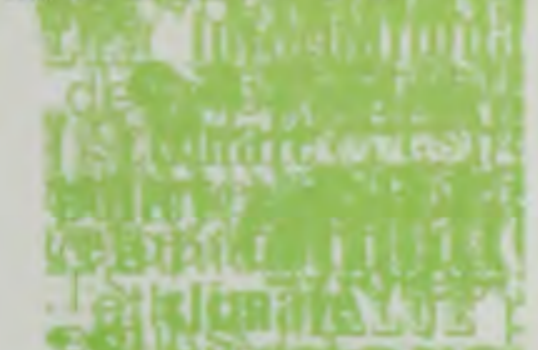

आIS:

development

EMISSIONS a i $r$

people (1)

international wa t e $r$

MRSA

CHANGE

Fisheries Cass

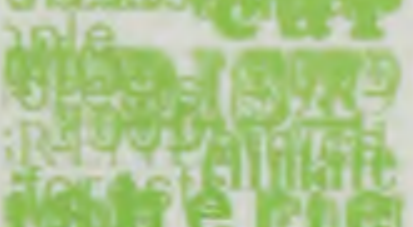

aline

loloreotshics

gago ic

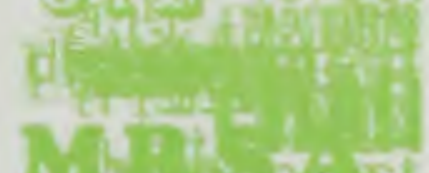

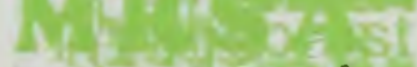

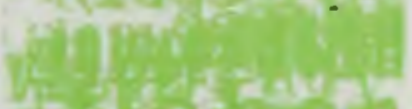

$8+196$

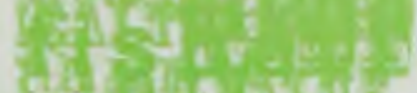

\section{forests}

electricity

policy pood

RENEWABLE 



\title{
ISSUES OF THE DAY
}

\author{
100 Commentaries on Climate, Energy, \\ the Environment, Transportation, \\ and Public Health Policy
}

Ian W.H. Parry and Felicia Day, editors

RESOURCES FOR THE FUTURE

Washington, DC, USA 
Copyright (C) 2010 by Resources for the Future. All rights reserved.

No part of this publication may be reproduced by any means, whether electronic or mechanical, without written permission. Requests to photocopy items for classroom or other educational use should be sent to the Copyright Clearance Center, Inc., Suite 910, 222 Rosewood Drive, Danvers, MA 01923, USA (fax +1 978646 8600; www.copyright.com). All other permissions requests should be sent directly to the publisher at the address below.

Resources for the Future

1616 P Street NW

Washington, DC 20036-1400

USA

www.rff.org

\section{EDITORS:}

Ian W.H. Parry, series editor Felicia Day, managing editor

Adrienne Foerster, assistant editor

\section{CONTRIBUTING EDITORS:}

John Anderson

Sally Atwater

\section{COVER AND BOOK DESIGN:}

Ellen A. Davey

The findings, interpretations, and conclusions offered in this publication are those of the authors. They do not necessarily represent the views of Resources for the Future, its directors, or its officers.

Distributed by RFF Press, an imprint of Earthscan

9781933115887 (hardback)

9781933115870 (paperback) 


\section{TABLE OF CONTENTS}

EDITORS' INTRODUCTION.

Ian W.H. Parry and Felicia Day

\section{PART 1}

Global Environmental Challenges.

1. Stabilizing Atmospheric $\mathrm{CO}_{2}$ with Incomplete International Cooperation.

Jae Edmonds, Leon Clarke, and Marshall Wise

2. A Pragmatic Global Climałe Policy Archiłecture......... 4

Valentina Bosetti and Jeffrey Frankel

3. Thinking Beyond Borders Why We Need to Focus on Global Public Goods.

Scott Barrett

4. The Value of Climate-Related Satellite Data ....8

William Gail

\section{The Successful International Response to}

Stratospheric Ozone Depletion...

James Hammitt

6. Evaluating Europe's Plan for Reducing Greenhouse

Gases

Dallas Burtraw

7. U.S. Climate Change Policy Previewing the Debate.....14 Daniel S. Hall

8. Which Is the Better Climate Policy? Emissions Taxes versus Emissions Trading. ....16

Inn W.H. Parry and Williain A. Pizer

\section{Should Cap-and-Trade Systems Be Supplemented} with Renewable Portfolio Standards? .. .18

Christoph Böhringer and Knut Einar Rosendahl
10. Inducing Innovation for Climate Change Mitigation.

Richard G. Neucll

11. How Should Emissions Allowance Auctions Be Designed?..

Karen Palmer

12. Competitiveness, Emissions Leakage, and Climate Policy

Caroly'n Fischer and Richard D. Morgenstern

13. Addressing Biodiversity and Global Warming by Preserving Tropical Forests...

Roger A. Sedjo

14. Forests in a U.S. Climate Program Promising, but the Key Is Implementation. .28

Kenneth R. Richards

15. Emissions Offsets in a Greenhouse Gas Cap-andTrade Policy.

Brian C. Murray

16. Ethics and Discounting Global Warming Damages. . .32

Cameron Hepburn

17. Climate Change Abatement Not "Stern" Enough?......34 Dallas Burtraw and Thomas Sterner

18. Evaluating Climate Risks in Coastal Zones.... .36

Gary Yohe

\section{PART 2}

Energy Policies.

19. Reflections on Three Decades of U.S. Energy Policy. .40

Phil Sharp 
iv Issues of the Day

20. The Oil Securify Problem "Déjà Vu All

Over Again". 42

Hillard Huntington

21. Reassessing Oil Securify. .044

Stephen P.A. Brown

22. The 2008 Oil Price Shock Markets or Mayhem?

James L. Smith

23. The Cost of Profecting Oil in the Persian Gulf. 48

Mark Delucchi

24. What Role for "Synthetic" Liquid Fuels? A Look at

Canadian Oil Sands. .50

Joel Darmstadter

25. FutureGen How to Burn Coal-Maybe-Without

Contributing to Climate Change .52

John W.Anderson

26. The Economics of New Green Technology

Invesiment The Case of Satellite Solar Power. .54

Molly K. Macauley and Jhih-Shyang Shih

27. Oil and the Arctic National Wildlife Refuge. .56

Matthew Kotchen and Nicholas Burger

28. Oil Spills The Deterrent Effects of Monitoring, Enforcement, and Public Information.

Mark A. Cohen

29. Taking a Closer Look at Energy Subsidies in the Federal Tax Code.

Gilbert E. Metcalf

30. Learning by Doing and the California Solar Initiative.

Kenneth Gillingham, Arthur van Benthem, and James L. Sweeney

\section{Opposing the Chicken or Opposing the Egg? New}

Challenges in Siting Networked Energy Facilities. .64

Shalini Vajjhala

32. The Greening of Buildings George S. Tolley and Sabina Shaikh
33. Why International Nafural Gas Markets Matter in Today's Energy and Environmental Picture. .68

Steven A. Gabriel

34. Assessing Electricity Markets Prospects and Pitfalls. .70

Timothy Brennan

\section{PART 3}

National Environmental Policies

35. What Are the Biggest Environmental Challenges Facing the United States?

Paul R. Portney

36. Where Things Stand with Hazardous Waste

Regulation .76

Sarah Stafford

37. Reinstating the Superfund Taxes Good or Bad Policy?

Kate Probst

38. Trash Talk.

Don Fullerton and Margaret Walls

39. The New Economics of Managing the Nation's Waste.

Molly K. Macauley and Stephen W. Salant

40. Enhancing Productivity while Safeguarding Environmental Quality.

David Zilberman and Steven Sexton

41. Why We Need to Treat Nitrogen as a Systems

Problem

Andrew Manale

42. The Effectiveness of Voluntary Environmental Programs. .88

Richard D. Morgenstern and William A. Pizer

43. Does Green Corporate Social Responsibility Benefit Sociefy? .90

Thomas P. Lyon and John W. Maxwell 
44. The Evolving $\mathrm{SO}_{2}$ Allowance Market Title IV, CAIR, and Beyond.

Karen Palmer and David A. Evans

45. The Cooling Water Intake Structures Rule.

Winston Harrington

46. The Future of Regulatory Oversight and

Analysis. . .96

Susan E. Dudley and Art Fraas

47. A Plea for Environmental Accounts. . .98

Jaines Boyd

48. The Political Economy of Environmental Justice...100

Spencer Banzhaf

49. Overcoming Distributional Obstacles to MarketBased Environmental Policies.

Roberton Willians

50. What Do the Damages Caused by U.S. Air Pollution Cost?. . .104

Robert Mendelsolin and Nicholas Z. Muller

\section{What Can Policymakers Learn from Experimental}

Economics?. . .106

Jolin' List

52. Environmental Federalism. .108

Wallace E. Oates

\section{PART 4}

MANAGING NATURAL RESOURCES.

53. Can Catch Shares Save Fisheries?.

Christopher Costello and Steven Gaimes

54. The Political Economy of Addressing Overfishing in U.S. Waters. .114

Harrison Fell and Janes N. Sanchirico

55. Achieving Efficient Coordination and Acceptance in Fishery Reform. .116

Robert T. Deacon
56. Restoring Great Lakes Ecosystems Worth the Cost?

Soren Anderson, Jennifer Read, and Don Scavia

57. The Gulf of Mexico's Dead Zone Mess, Problem, or Puzzle? .120

Don Scavia

58. Information Disclosure and Drinking Water Quality.. .122

Lori Suyder Bemmear and Sheila Olmstead

59. Western Water Law and Efficient Use of Water

Resources.

Charles Houre

60. A New Approach to Reforming the National Flood Insurance Program.

Leonard Shabman

61. Perverse Incentives and the Endangered Species

Act.

Jonathan H. Adler

62. Improving Invesiments in Biodiversity Conservation

Juha Siikamäki and Stephen Neubold

63. USDA's Conservation Reserve Program Is it Time to Ease into Easements?

Ralph Heimlich

64. How Should We Tackle the Forest Fire Problem?.

Arun Malik

65. Options Contracts for Contingent Takings Improving Disaster Management. .136

Carolyn Kousk'y, Sam Walsh, and Richard Zeckhauser

\section{PART 5}

Transportation and Urban Policies.

\section{Triple Convergence foward a Higher Gasoline} Tax.

Kenneth Sinall 
67. The Price of Gas and the Demand for Fuel Economy

Are There Any Links?

Thomas H. Klier and Joshua Linn

68. Should Distributional Considerations Hold Up

Higher Gasoline Taxes?

Sarah E. West

69. Does the Federal Government Spend Too Much for Highways, or Too Little? 146

IVinston Harrington

\section{The Benefits and Costs of Tighter Fuel Economy}

Regulations.

Ian IV.H. Parry

71. Pay-as-You-Drive Auto Insurance.

Jason Bordoff and Pascal Noel

72. What Motivates People to Buy Hybrids?

Slinilun Li

73. The Outlook for Hydrogen Cars

Joan Ogiden and Edward S. Rubin

74. Useful Lessons from California's Experiment with Congestion Pricing.

Robert IV. Poole, Jr.

75. Congestion Pricing Lessons from London.

Jonatlan Leape

76. Has the Time Come for Truck-OnlyToll Lanes?.......160 Robin Lindsey

77. Using the Price System to Reduce Airport

Congestion.

Jan K. Brueckner and Kurt Van Dender

78. Delayed Is Privatizing America's Airports the

Answer?

Clifford Winston and Ginés de Rus

79. Telecommuting What is it Good For?. 166

Elena Safirova
80. Declining Traffic Fatalities Lessons for Developing

Countries?

Maureen Cropper and Elizabeth Kopits

81. Preservation and Development Can TDRs Improve Land Markets?

Virginia McConnell and Margaret Walls

82. Is there an "Efficient" Way to Address Suburban Sprawl?

Antonio M. Bento

\section{PART 6}

Public Health Policies

83. The Value of Health and Longevity.

Kevin M. Murply and Robert H. Topel

84. How U.S. and Chinese Citizens Feel about Reducing Morfalify Risks

Alan Krupuick

85. A New Chapter in the History of Malaria

Control

Macicj F. Boni and David L. Smith

86. The Spread of MRSA Antibiotic Resistance with a Name

Hellen Gelband

87. Controlling Tuberculosis What Is the Benefit, at What Cost?

Rarmanan Laxminarayan, Eili Klein, and Saralı Darley

88. Bringing Our Food Safety Sytem into the 21 st

Century. 186

Sandra A. Hoffinann

89. Tobacco Taxation in the European Union and United States.

Sijbren Cnossen

90. How Advertising for Smoking-Cessation Products Can Help Meet Public Health Goals. 
Jay Shimshack

92. Measuring the Benefits of Reduced Exposure to Lead..

Felicia Day

93. Indoor Air Pollution and African Death Rates

Majid Ezzati

\section{PART 7}

Environment and Development. 199

94. Driving Restrictions and Air Quality in Mexico City

Lucas W. Davis

95. Deciphering the Demand for Safe Drinking Water in Low-Income Countries.

Michael Kremer, Edward Miguel, Clair Null, and Alix Zwane

\section{Environmental Policy Innovations in Developing}

Countries.

Allen Blackman

97. Green Cities and Economic Development.

Matthou E. Kahı

\section{Building Beffer Housing Policies for the Developing}

World's Poor 208

Robert M. Buckley and Jerry Kalarickal

99. The Future of Famine

Cormac Ó Gráda

100. Is Population Still an Important Policy Issue?......212 Warren C. Robinson 


\section{WHERE THINGS STAND WITH HAZARDOUS WASTE REGULATION}

\author{
Sarah Stafford \\ is the Verkuil Distinguished As- \\ sociate Professor of Economics \\ and the associate director of the \\ Thomas Jefferson Program in Public \\ Policy at the College of William \\ and Mary. Her research focuses \\ on hazardous waste regulation \\ and corporate environmental \\ behavior, with an emphasis on \\ compliance and enforcement.
}

One problem in hazardous waste regulation is the difficulty of ensuring regulatory compliance, not least because violations are often inadvertent. Therefore, complementary programs, such as compliance assistance, environmental audits, and voluntary compliance initiatives, can play a valuable role.

The U.S. economy generates a significant amount of waste. According to recent estimates, on average we generate about 250 million tons of trash each year, or 4.5 pounds per person per day. In addition to municipal solid waste, the United States generates $\mathbf{5 0}$ million more tons of hazardous waste each year.

Hazardous waste is a relatively new phenomenon and was not generated in significant quantities until we started using fossil fuels and chemicals in earnest at the beginning of the industrial age. Initially it was not considered to be any different from other waste and so was essentially unregulated. Hazardous constituents were routinely released into the environment, where they polluted groundwater, rivers, and lakes and killed people, livestock, and wildlife. As the consequences of uncontrolled management of waste became clear, the public began to call for regulations to protect human health and the environment.

\section{FIRST, SOME HISTORY}

The first environmental law that specifically addressed the generation and management of hazardous waste was the Resource Conservation and Recovery Act (RCRA), passed in 1976. RCRA's Subtitle C delineated the basic structure of federal hazardous waste regulation and required EPA to establish criteria for identifying and listing hazardous waste and to develop standards applicable to generators, transporters, and managers of hazardous waste. In 1984, Congress passed the Hazardous and Solid Waste Amendments (HSWA), which expanded the scope of RCRA by requiring EPA to develop treatment standards for hazardous waste, minimum technological requirements for hazardous waste management units, and a corrective action program for contamination at active waste management facilities. Together these two acts provide the mandate for EPA's current hazardous waste program, commonly referred to as the RCRA program, which covers hazardous waste "from the cradle to the grave."

Although hazardous waste is often referred to as toxic waste, a material does not have to be toxic to be considered hazardous. Hazardous waste includes any discarded material that is potentially harmful to human health and the environment because it is ignitable, corrosive, reactive, or toxic, as long as the material has not been specifically excluded from the definition of hazardous waste. Two major categories of waste have the potential to be classified as hazardous but have explicitly been excluded from regulation as such-agricultural and mining wastes.

Even with these exclusions, the RCRA-regulated universe is both large and diverse, including well over 600,000 facilities in the United States, ranging from large chemical manufacturers and petroleum refiners to small dry cleaners and photo finishers. Nonprofit and government entities, such as hospitals, universities, and military bases, generate hazardous waste as well.

Interestingly, perhaps the most well-known toxic waste sites-Superfund sites-are not part of the RCRA universe. The Superfund program was established separately to cover cleanup of hazardous waste at inactive or abandoned sites and hazardous waste 
spills that require an emergency response, whereas RCRA covers only active hazardous waste facilities.

\section{MUCH SKEPTICISM}

RCRA is a relatively mature program, and over the past decade there have been only minor changes to hazardous waste regulations. With no new regulations to implement, EPA has turned its focus toward waste minimization and improving regulatory compliance.

Waste minimization, which includes both pollution prevention and increased recycling, has been promoted primarily through voluntary initiatives such as WasteWise, the $\mathrm{Na}$ tional Environmental Performance Track, and Responsible Care. The majority of these programs are cross-media and, in theory, have the potential to increase environmental performance because they encourage facilities to think holistically about their environmental impacts. Both industry and EPA have been enthusiastic about such programs, but many in the environmental community are more doubtful because of the general lack of public accountability or oversight.

Over the past few years, researchers have conducted a number of studies to analyze the effectiveness of voluntary environmental programs. Only a few have been able to show that voluntary programs can significantly improve performance for more than a limited set of facilities. This lack of evidence may be behind EPA Administrator Lisa Jackson's suspension of the National Environmental Performance Track.

Under previous EPA administrators, voluntary programs were not limited only to waste minimization efforts; during the Bush administration, the agency placed increased emphasis on voluntary compliance initiatives and self-policing. But still, neither voluntary nor command-and-control approaches appear adequate to get the job done. Many are skeptical that voluntary efforts are effective at increasing compliance, while others doubt that traditional enforcement can bring all facilities into compliance because many violations appear to be due to confusion or ignorance, rather than deliberate decisions to violate the rules.

Although a facility may knowingly violate RCRA regulations by sending hazardous waste to a nonhazardous waste landfill for disposal, it may also inadvertently violate regulations if one of its hazardous waste storage tanks leaks. Traditional enforcement measures, such as inspections and fines, can help decrease the level of deliberate violations by making violations more expensive for the facility. When EPA revised its RCRA penalty policy in 1991 by drastically increasing its fines to 10 or 20 times the previous fine levels, hazardous waste compliance increased. Similarly, increasing the probability of a compliance inspection has been shown to increase the likelihood that a facility will comply with $\mathrm{RCRA}$ regulations.

For inadvertent violations, however, increasing penalties and inspections may not be very effective at increasing compliance. Facilities may be noncompliant because they do not fully understand the regulatory requirements, do not fully know their facility's operations, have poor internal environmental management systems, or do not have the ability to comply. Alternative policies such as compliance assistance or environmental audits may help to increase compliance.

In my research, I have found some evidence to support the effectiveness of compliance assistance programs. In a study on RCRA compliance behavior to try to determine whether facilities were deliberately or inadvertently violating hazardous waste regulations, facilities in states with compliance assistance programs were found to be less likely to violate than facilities in states without them. Environmental auditing has not been shown to be as effective. While facilities in states with environmental audit privilege and self-policing policies are less likely to violate, a more recent study of Michigan hazardous waste facilities suggests that facilities that implement environmental audit programs are not any more likely to be in compliance than facilities that do not audit.

Although the data on the ability of voluntary compliance programs to improve environmental performance are limited, I nonetheless believe that there is an important role for such programs to play in complementing traditional enforcement and improving compliance in the future. Facilities violate hazardous waste regulations for a variety of reasons, and we must develop an equally wide range of initiatives and programs to increase compliance. Voluntary programs should not supplant traditional enforcement efforts but instead should be used in tandem.

\section{Further Reading}

Evans, Mary, Lirong Liu, and Sarah Stafford. 2009. A Facility-Level Analysis of the Long-Term Consequences of Environmental Auditing among Hazardous Waste Generators. Department of Economics Working Paper 78. Williamsburg,VA: College of William and Mary.

Khanna, Madhu, and Keith Broulhle. 2008. Effectiveness of Voluntary Environmental Initiatives. In Governing the Environment: Interdisciplinury Perspectives, edited by M. Delmas and O. Young. Cambridge, UK: Cambridge University Press.

Porter, Richard C. 2002. The Economics of Waste. Washington, DC: RFF Press.

Stafford, Sarah L. 2006. Rational or Confused Polluters? Evidence from Hazardous Waste Compliance. Contributions to Economic Analysis and Policy 5: Article 21. 